\title{
Bleeding on Probing
}

National Cancer Institute

\section{Source}

National Cancer Institute. Bleeding on Probing. NCI Thesaurus. Code C74951.

Bleeding that is induced by gentle manipulation of the gingival tissue at the depth of the gingival sulcus. 